\title{
Provision of long-term renal replacement therapy to non-national patients in South Africa
}

\author{
M Davies, MB BCh, FCP (SA), Cert Nephrology (SA) Phys, MMed (Int Med); \\ Z Cassimjee, MB BCh, FCP (SA), Cert Nephrology (SA) Phys, MMed (Int Med) \\ Division of Nephrology, Helen Joseph Hospital, and Faculty of Health Sciences, University of the Witwatersrand, Johannesburg, South Africa
}

Corresponding author: $M$ Davies (malcolm.davies@wits.ac.za)

\begin{abstract}
Dialysis is a life-saving but costly therapy, which in the local context may be considered to be a constrained resource. The residual effects of South Africa (SA)'s historical inequalities and the pathophysiology of chronic kidney disease in our population result in significant demand being placed upon state dialysis units, which consequently are forced to ration access to treatment. Although such rationing is undertaken with due regard to local and international protocols, state units have been subject to legal challenge. Consequently, jurisprudence relevant to the provision of dialysis and other similarly resource-constrained therapies has evolved. In this article, we discuss a recent case that led to a landmark ruling on the access of non-SA nationals to dialysis, contextualised against existing guidelines and legislation and the status of renal replacement therapy in this country.
\end{abstract}

S Afr Med J 2021;111(7):615-619. https://doi.org/10.7196/SAMJ.2021.v111i7.15395

A 44-year-old foreign national presented to the Division of Nephrology at Helen Joseph Hospital, Johannesburg, South Africa (SA) with undifferentiated uraemia requiring emergent initiation of acute haemodialysis. Subsequent investigation was consistent with lupus nephritis. Induction immunosuppression was prescribed, which was complicated by the development of nosocomial pneumonia requiring mechanical ventilation. Following recovery, a renal biopsy was performed, and the patient was discharged to temporary outpatient haemodialysis to await pathology results. Upon histological diagnosis of lupus nephritis World Health Organization (WHO) class VI, the patient and family were counselled regarding the need for long-term renal replacement therapy (LTRRT) and, in view of the patient's temporary immigration status and long-standing shortage of chronic dialysis slots at the hospital, were advised to pursue further treatment in the patient's country of origin; outpatient dialysis was extended to facilitate repatriation. Lawyers for Human Rights, acting on the patient's behalf, lodged an application in the High Court, seeking to compel the hospital to continue dialysis on a permanent basis. In court papers and a media campaign, it was alleged that in denying the patient access to LTRRT the hospital had violated the patient's constitutional right to health. Local policy and jurisprudence provide for the limitation of the right to LTRRT access in respect of medical fitness for transplantation. While immigration status is not explicitly recognised as a dialysis exclusion criterion, state units have in consideration of international guidelines not provided LTRRT to temporary residents. The ruling by the High Court in the present case in favour of the hospital affirms the rationality of this approach given local resources, and confirms the authority of medical professionals in oversight of access to dialysis. This article contextualises this judgment against local and international policy and the broader reality of LTRRT availability in SA.

\section{End-stage renal failure and access to long-} term renal replacement therapy in SA

A complex interplay of genetic and socioeconomic factors contributes to the development of end-stage renal failure (ESRF) in SA. The local penetrance of apolipoprotein L1 (APOL1) allelic variants, which have been associated with an increased risk of focal segmental glomerulosclerosis, HIV-associated nephropathy and hypertension-associated ESRF, ${ }^{[1]}$ has been reported to be between $10 \%$ and $30 \% .{ }^{[2]}$ Reduced maternal socioeconomic status is known to be an important contributor to the lifetime risk of ESRF in offspring, an association believed to derive from reduced nephron endowment due to insufficient in utero nephrogenesis. ${ }^{[3]}$ This effect of the prenatal environment may be potentiated by social changes, such as urbanisation, in which increased access to a salt- and calorie-enriched diet facilitates the development of metabolic disease associated with chronic kidney disease (CKD) progression to ESRF. ${ }^{[4]}$ Such ESRF risk factors particularly affect black South Africans, and lead to the significant demand for LTRRT in this ethnic group. ${ }^{[5]}$

Dialysis is a life-saving therapy for patients afflicted with ESRF. Currently, there are 29 state and 249 private dialysis units in SA; ${ }^{[5]}$ the private sector has the capacity to provide treatment for 855 patients per million population (pmp) compared with the state sector's 66 pmp. ${ }^{[5]}$ Whereas dialysis in public hospitals is fully subsidised by the state, in the private sector the individual patient must fund this therapy. Due to the prohibitive costs involved in financing such treatment, dialysis in the private sector is usually achieved through recourse to healthcare insurance plans. Membership of such plans mirrors the racial socioeconomic inequalities of the country $-9.9 \%$ of the black community have medical aid compared with $72.2 \%$ of whites and $16.4 \%$ of the population as a whole. ${ }^{[6]}$ This situation results in significant disparity in access to LTRRT for the population most at risk of ESRF. Although black South Africans account for $80.8 \%$ of the total population, the prevalence of LTRRT in this group is 126 pmp compared with $442 \mathrm{pmp}$ for whites, who comprise $8 \%$ of the population. ${ }^{[5]}$

This disparity is unlikely to improve. In the two decades since 1994 , the number of private dialysis units increased by $3820 \%$ in response to the demands of an expanding population; in contrast, the number of state dialysis units decreased relative to population growth ${ }^{[7]}$ At the same time, the absolute number of renal transplants 
undertaken in the state sector has declined. ${ }^{[8]}$ Meanwhile, the number of qualified nephrologists to oversee LTRRT remains inadequate at 2.5 pmp, below the continental average of $3.6 \mathrm{pmp}$, with only $50.6 \%$ of nephrologists practising in the state sector. ${ }^{[9]}$ The numbers of appropriately skilled nurses and technologists, upon whom actual administration of LTRRT depends, have also been reported to be decreasing. ${ }^{[10]}$

Cost remains an important limitation to the expansion of the state LTRRT programme. Recent analysis estimated the cost per patient per year for haemodialysis to be USD31 993.21, and USD25 282.39 for peritoneal dialysis (ZAR446 153.63 and ZAR352 569.50, respectively, at a ZAR:USD exchange rate of 13.95:1 current at the time of writing). ${ }^{[11]}$ Fixed costs (facility and dialysis machines) contribute significantly to the cost of haemodialysis, while dialysate fluid and other consumables are the chief cost drivers for peritoneal dialysis. ${ }^{[11]}$ Although public-private partnerships (PPPs) have been advocated as a means to reduce these costs and rapidly expand dialysis availability to the state sector, ${ }^{[7]}$ analysis from such a PPP dialysis unit at Pietersburg Hospital reported higher costs for haemodialysis and peritoneal dialysis than those reported by contemporaneous estimations for SA as a whole, in part due to the application of additional outsourcing fees. ${ }^{[12]}$

As a result of the pernicious constraints on availability, access to dialysis has been rationed since the inception of this therapy in SA. ${ }^{[10]}$ Available data indicate that the majority (52.7 - 53.9\%) of patients with ESRF presenting to state facilities are not offered LTRRT. ${ }^{[10,13]}$ Local policy and jurisprudence provide for such exclusion on medical criteria, specifically fitness for renal transplantation. ${ }^{[14,15]}$ Whether immigration status is an exclusion criterion has hitherto been less clear and is considered in further detail below.

\section{Access to dialysis for non-nationals: SA policy}

Under the Bill of Rights, all persons living in SA have the right to access to healthcare services, and refusal of emergency medical treatment is expressly prohibited. ${ }^{[16]}$ The right to have access to therapy is best interpreted as the right to be considered for a treatment and does not equate to the right to receive intervention. Indeed, the Constitution implicitly recognises that universal and comprehensive healthcare has yet to be realised. ${ }^{[16]}$ Reflecting this, the Constitutional Court ruled in Soobramoney $v$ Minister of Health that, in consideration of resource constraints, the right to receive dialysis can be limited by transplant eligibility. ${ }^{[15]}$

Government policy acknowledges that LTRRT is not freely available to all and urges clinicians to apply transplant eligibility criteria in the selection of patients for dialysis in the state sector with the aim of achieving equitable access to chronic dialysis for 'all South African citizens and permanent residents' (own emphases). ${ }^{[14]}$ Although not explicitly stated, this can be construed as excluding non-nationals from LTRRT and is consistent with the National Health Act, ${ }^{[17]}$ which prohibits the allocation of deceased donor organs to patients who are not SA citizens or permanent residents, without written consent from the Minister of Health.

\section{Access to dialysis for non-nationals: Interinational policy}

Restriction of the provision of LTRRT to non-nationals is not unique to SA and should be contextualised against policies adopted by other countries and regulatory protocols to which SA is a signatory.

United Nations (UN) conventions provide a framework for the formulation of health policy by individual state signatories. The International Covenant on Economic, Social and Cultural Rights
(ICESCR) obliges state signatories to recognise the right of every individual to the enjoyment of the highest attainable standard of health and to take steps towards the creation of conditions that allow for the provision of medical services to all without discrimination. ${ }^{[18]}$ While UN conventions guarantee emergency medical treatment, regardless of immigration status, ${ }^{[19]}$ commentary provided by the Office of the High Commissioner for Human Rights (OHCHR) has clarified that practical achievement of this right may be limited by the availability of a particular intervention in individual states. ${ }^{[20]}$ Although the laudable aim of these treaties is to ensure provision of healthcare to social and economic migrants, they may be criticised for providing an opportunity for medical tourism (immigration for the purpose of accessing treatment), which may result in the diversion of resources from citizens to non-nationals, leading to a loss of self-sufficiency by signatory states. The Declaration of Istanbul (DOI), which provides an ethical guide for transplantation, requires healthcare professionals of all signatory states to prevent medical tourism and to strive for self-sufficiency in this field (Table 1). ${ }^{[21]}$

On the eve of the DOI, a WHO report identified India, Pakistan and China as significant sources of exported organs. Although a less substantial contributor to transplant tourism, the Philippines was noted to be moving towards the development of legislation to permit the sale of organs to foreigners. ${ }^{[22]}$ Transplantation of non-nationals is not prohibited by current Chinese regulations; ${ }^{[23]}$ the use of organs allegedly procured from executed prisoners, and the reported existence of brokers to facilitate the prioritisation of foreign recipients due to their ability to pay, have been reported. ${ }^{[22,24]}$ In contrast, in response to the WHO report and DOI, Indian policies were formulated that permit foreigners to receive transplants only from related living donors, ${ }^{[25]}$ and Pakistan promulgated legislation that specifically excludes non-nationals from engraftment. ${ }^{[26]}$ The Philippines enacted laws that not only banned the sale of transplant organs, but also effectively prohibited the transplantation of foreigners. ${ }^{[27,28]}$ The effect of the DOI has therefore been the formulation of countryspecific regulations, which seek to maintain self-sufficiency in LTRRT. In general, nations with greater transplantation resources may permit limited access to LTRRT for non-nationals, while those with fewer resources tend to exclude such patients from their programmes (Table 2). ${ }^{[14,17,25,26,28,29-35]}$

\section{Discussion}

SA is unique on the continent in having a state-funded nationwide chronic dialysis and transplantation programme, the capacity of which exceeds that of any other African state. ${ }^{[36]}$ A shortage of treatment availability in their country of origin and the cost of self-funded dialysis contribute to non-nationals seeking dialysis in local state hospitals. The relative wealth of SA and comparative wider availability of medical therapies have been advanced as ethical imperatives to accommodate foreign nationals on this country's state-funded dialysis programme. However, this apparent resource abundance belies an objective truth: the state lacks sufficient resource capacity to provide LTRRT to all South Africans requiring it.

The effect of this limitation is most significant for the black African population, who are most at risk of ESRF and who are most reliant on the state sector for treatment. SA has in recent years experienced regular bouts of xenophobia. Surveys indicate that xenophobic attitudes in SA are widespread and independent of income group or race, with up to $78 \%$ of the citizenry in favour of the total prohibition of further immigration to the country, and $50 \%$ supporting deportation of all non-nationals. ${ }^{[37]}$ Such sentiments have nevertheless been most overtly demonstrated in low-income and informal urban areas, reflecting the nuanced aetiology of this 


\section{Table 1. Principles of the Declaration of Istanbul ${ }^{[21]}$}

1. Governments should develop and implement ethically and clinically sound programmes for the prevention and treatment of organ failure.

2. The optimal care of organ donors and transplant recipients should be a primary goal of transplant policies and programmes.

3. Trafficking in human organs and trafficking in persons for the purpose of organ removal should be prohibited and criminalised.

4. Organ donation should be a financially neutral act.

5. Each country or jurisdiction should develop and implement legislation and regulations to govern the recovery of organs from deceased and living donors and the practice of transplantation, consistent with international standards.

6. Designated authorities in each jurisdiction should oversee and be accountable for organ donation, allocation and transplantation practices to ensure standardisation, transparency, quality, safety and fairness.

7. All residents of a country should have equitable access to donation and transplant services and to organs procured from deceased donors.

8. Organs for transplantation should be equitably allocated within countries or jurisdictions in conformity with objective, non-discriminatory, and transparent rules, guided by clinical criteria and ethical norms.

9. Health professionals and institutions should assist in preventing and addressing organ trafficking, trafficking in persons for the purpose of organ removal and transplant tourism.

10. Governments and health professionals should implement strategies to discourage and prevent the residents of their country from engaging in transplant tourism.

11. Countries should strive to achieve self-sufficiency in organ donation and transplantation.

Table 2. Comparison of national policies on access to long-term renal replacement therapy

\begin{tabular}{|c|c|}
\hline Country & Nature of guideline \\
\hline South Africa & $\begin{array}{l}\text { Legislation: } \\
\text { National Health Act } 61 \text { of } 2003 \\
\text { Policy: Guideline for chronic dialysis, } 2009\end{array}$ \\
\hline Brazil & $\begin{array}{l}\text { Policy: Technical regulation of the National } \\
\text { Transplant System (Ordinance } 2600 \text { of 2009) }\end{array}$ \\
\hline Egypt & Legislation: Law on Organ Transplantation \\
\hline $\begin{array}{l}\text { European Union } \\
\text { (Germany, Austria, the } \\
\text { Netherlands, Belgium) }\end{array}$ & $\begin{array}{l}\text { Policy: Eurotransplant International } \\
\text { Foundation }\end{array}$ \\
\hline France & $\begin{array}{l}\text { Policy: Etablissement Francais des Greffes } \\
\text { (ETIF) }\end{array}$ \\
\hline India & $\begin{array}{l}\text { Policy: Transplantation of Human Organs and } \\
\text { Tissues Rules }\end{array}$ \\
\hline Pakistan & $\begin{array}{l}\text { Legislation: The Transplantation of Human } \\
\text { Organs and Tissues Act }\end{array}$ \\
\hline The Philippines & Legislation: Organ Donation Act \\
\hline UK & Policy: NHS Blood and Transplant \\
\hline USA & $\begin{array}{l}\text { Legislation: National Organ Transplant Act } \\
\text { (NOTA) } \\
\text { Policy: Organ Procurement and Transplantation } \\
\text { Network (OPTN) }\end{array}$ \\
\hline
\end{tabular}
Summary of guideline

Transplantation of foreigners precluded without written permission of the Minister of Health ${ }^{[17]}$

Aims for equity of access to LTRRT for South African citizens and permanent residents

State dialysis units should use transplant eligibility as entrance criteria for chronic dialysis

Transplant eligibility depends on medical criteria ${ }^{[14]}$

Transplants from any type of donor to foreign residents who do not have permanent residence are prohibited ${ }^{[29]}$

Non-Egyptians may only receive transplants from Egyptians if donor and recipient have been married for at least 3 years ${ }^{[30]}$

Listing of foreigners is discouraged

Residency status of potential recipients must be provided at the time of listing ${ }^{[31]}$

Foreigners may be listed provided proof is received that transplantation is unavailable in their country of origin and that the patient has funds to pay for the transplantation process ${ }^{[32,33]}$

Foreigners may only receive transplantation from a living related donor ${ }^{[25]}$

Foreigners are excluded from transplantation ${ }^{[26]}$

Foreigners may only be transplanted if their country of origin has tissue exchange treaties with the Philippines ${ }^{[28}$

Foreigners may be listed as second-tier potential recipients and are only eligible to receive a graft if no first-tier (British subject) is suitable ${ }^{[34]}$

Transplant eligibility depends on medical criteria ${ }^{[35]}$

Foreigners may be listed for transplant; any programme with $>5 \%$ foreigners on its waitlist is audited for listing processes ${ }^{[35]}$

LTRRT $=$ long-term renal replacement therapy; NHS = National Health Service

phenomenon: xenophobic violence reflects displaced frustration on the part of the historically disadvantaged with the slow pace of service delivery by the post-apartheid government, leading to the dream deferred of equal access to SA's resources, including healthcare. ${ }^{[38]}$

Perceptions of competition for resources on the part of the urban black poor are likely to be reinforced by immigration to SA cities. ${ }^{[38]}$ SA has consistently ranked in the top 10 countries with the highest levels of net immigration from 2000 to 2019; ${ }^{[39]}$ the total number of immigrants (documented and undocumented) resident in the country has been estimated at 3 million persons. ${ }^{[40]}$ Although economic opportunity is the main driver of such immigration, the probability of accessing healthcare in SA increases with duration of stay, with $45 \%$ of immigrants reporting attendance at public medical facilities. ${ }^{[0]}$ Medical tourism nevertheless contributes significantly to the use of 
public health facilities by non-nationals: between 2006 and 2012, in excess of 2.6 million immigrants in SA on temporary visitor permits received treatment in the country; $67.4 \%$ of these patients originated from three countries - Lesotho, Mozambique and Zimbabwe. ${ }^{[41]}$ The availability of LTRRT in these countries is poor, with a paucity of certified nephrologists and a lack of dialysis units; therapy is only partially subsidised by the governments of Mozambique and Lesotho and not subsidised by the government of Zimbabwe. ${ }^{[42]}$ Just as these states cannot provide LTRRT to citizens of this country, SA's limited LTRRT resources cannot be stretched to accommodate an influx of non-national ESRF patients from these countries.

Indeed, constrained local resources have long required that state units ration access to therapy. ${ }^{[10]}$ Local policy ${ }^{[14]}$ and jurisprudence ${ }^{[15]}$ permit dialysis rationing according to transplant eligibility. Rates of transplantation are declining in $\mathrm{SA},{ }^{[8]}$ and the injunction of the DOI to maintain transplant self-sufficiency ${ }^{[21]}$ can be read as supporting the exclusion of non-nationals in this setting. Excluding nonnationals from LTRRT is permitted in resource-constrained settings by the ICESCR, ${ }^{[19,20]}$ and is consistent with policies adopted by other programmes (Table 2). Furthermore, since prolonged survival on dialysis is possible in patients with medical contraindications to transplantation, including non-nationals who do not automatically qualify for engraftment on LTRRT programmes, while excluding transplant-ineligible South Africans, may constitute a significant conflict of ethics.

Helen Joseph Hospital has the capacity to provide LTRRT to 156 ESRF patients. Since 2018, the Renal Unit Committee has excluded 183 patients from dialytic support, comprising 70 (38.25\%) exclusions on the basis of immigration status, 69 (37.70\%) due to medical ineligibility for transplant, and $44(24.4 \%)$ due to residence in another unit's drainage area (authors' data). The enforced provision of dialysis in the present case during the legal process precipitated an acute crisis in dialysis availability in the hospital; during this period 3 SA patients otherwise eligible for support died due to a lack of slots. The ruling by the High Court in the present case sets legal precedent in affirming that the right of non-nationals to receive LTRRT in the state sector may reasonably be rationed in consideration of available resources, and locates the responsibility for such decisions in the hands of medical rather than legal authorities. ${ }^{[43]}$ The ruling is therefore particularly important, as it preserves the ability of individual units to shepherd dialysis resources held in trust on behalf of the local community.

\section{Conclusions}

South Africans are at significant risk of developing ESRF, and such patients are likely to depend on the state sector for LTRRT. SA is distinguished in the region by having a state-sponsored LTRRT programme; however, the capacity of this programme is insufficient to meet the demands of the local population. Restricting nonnationals' access to LTRRT in SA is consistent with international protocols and agreements. Local jurisprudence has now affirmed the rationality of this approach and localises the responsibility for rationing access to LTRRT in the hands of appropriate medical specialist bodies who are best placed to know the healthcare needs of the local community. Usurpation of this role by other parties may hamper the appropriate provision of life-saving treatment.

\section{Key points}

- LTRRT is a constrained resource in SA.

- Local and international policies permit the rationing of access to LTRRT by non-nationals to ensure a just distribution of resources through the maintenance of state self-sufficiency.
- Recent jurisprudence affirms the authority of appropriate medical bodies in rationing individual patient access to therapy.

\section{Declaration. None.}

Acknowledgements. The authors gratefully acknowledge the support of the Division of Nephrology, Helen Joseph Hospital, in the preparation of this manuscript.

Author contributions. MD and ZC contributed equally to this paper.

Funding. None.

Conflicts of interest. None.

1. Limou S, Nelson GW, Kopp JB, Winkler CA. APOL1 kidney risk alleles: Population genetics and disease associations. Adv Chronic Kidney Dis 2014:21 (5):426-433. https://doi.org/10.1053/j.ackd.2014.06.005

2. Dummer PD, Limou S, Rosenberg AZ, Heymann J, Nelson G, Winkler CA. APOL1 in kidney disease . Dummer PD, Limou S, Rosenberg AZ, Heymann J, Nelson G, Winkler CA. APOL1 in kidney disease
variants: An evolving landscape. Semin Nephrol 2015;35(3):222-236. https://doi.org/10.1016/j. variants: An evolving
semnephrol.2015.04.008

3. Luyckx VA, Brenner BM. Birth weight, malnutrition, and kidney-associated outcomes - a global concern. Nat Rev Nephrol 2015;11(3):135-149. https://doi.org/10.1038/nrneph.2014.251

4. Jagannathan R, Patzer RE. Urbanization and kidney function decline in low and middle income countries. BMC Nephrol 2017;18(1):276. https://doi.org/10.1186/s12882-017-0685-4

5. Davids MR, Jardine T, Marais N, Zunza M, Jacobs JC, Sebastian S. South African Renal Registry annual report 2017. Afr J Nephrol 2019;22(1):60-71. https://doi.org/10.21804/22-1-3810

6. Statistics South Africa. General household survey. 2018. http://www.statssa.gov.za/publications/P0318 (accessed 19 July 2020).

7. Etheredge H, Fabian J. Challenges in expanding access to dialysis in South Africa - expensive modalities, cost constraints and human rights. Healthcare 2017;5(3):38. https://doi.org/10.3390/healthcare5030038 8. Moosa MR. The state of kidney transplantation in South Africa. S Afr Med J 2019;109(4):235-240. 8. Moosa MR. The state of kidney transplantation
https://doi.org/10.7196/SAMJ.2019.v109i4.13548

9. Hassen M, Archer E, Pellizzoni A, Chikte UME, Davids MR. Human resources for nephrology in 9. Hassen M, Archer E, Pellizzoni A, Chikte UME, Davids MR. Human resources for nephrology in
South Africa: A mixed methods study. PLoS ONE 2020;15:e0228890. https://doi.org/10.1371/journal. South Africa: A
pine. 0228890

10. Moosa MR, Kidd M. The dangers of rationing dialysis treatment: The dilemma facing a developing country. Kidney Int 2006;70(6):1107-1114

11. Makhele L, Matlala M, Sibanda M, Martin AP, Goodman B. A cost analysis of haemodialysis for the management of end-stage renal failure at an academic hospital in Pretoria, South Africa. PharmacoEconomics 2019;3:631-641. https://doi.org/10.1007/s41669-019-0124-5

12. Malatji TA, Wamukuo JT, Hyera FLM. An analysis of the direct cost of renal dialysis provided through a public-private partnership at a tertiary hospital in Limpopo Province, South Africa. S Afr Med J 2019;109(8):577-581. https://doi.org/10.7196/samj.2019.v109i8.13597

13. Kilonzo KG, Jones ESW, Okpechi IG, et al. Disparities in dialysis allocation: An audit from the new South Africa. PLoS ONE 2017;12:e0176041. https://doi.org/10.1371/journal.pone.017641

14. National Department of Health. Guidelines for Chronic Renal Dialysis. Pretoria: $\mathrm{NDoH}, 2009$.

15. Soobramoney v Minister of Health 1997 (CCT 32/97) SA (N).

16. South Africa. Constitution of the Republic of South Africa, 1996

16. South Africa. Constitution of the Republic of Sout
17. South Africa. National Health Act No. 61 of 2003.

17. South Africa. National Health Act No. 61 of 2003.

18. United Nations General Assembly. International Covenant on Economic, Social and Cultural Rights.
Resolution 2200A (XXI), 16 December 1966 .
19. United Nations General Assembly. International Convention on the Protection of the Rights of All 9. United Nations General Assembly. International Convention on the Protection of the Right
Migrant Workers and Members of Their Families. Resolution 45/158, 18 December 1990.

20. Office of the High Commissioner for Human Rights. CESCR general comment No. 14: The right to the highest attainable standard of health (Art. 12). 2000. https://www.refworld.org/pdfid/4538838d0. pdf (accessed 13 February 2020).

21. Steering Committee of the Istanbul Summit. Organ trafficking and transplant tourism and commercialism: The Declaration of Istanbul. Lancet 2008;372(9632):5-6

22. Shimazono $Y$. The state of the international organ trade: A provisional picture based on integration of available information. Bull World Health Organ 2007;85(12):901-908. https://doi.org/10.2471/ of available in
blt.06.039370

23. State Council of the People's Republic of China. Regulations on Human Organ Transplantation. Decree No. 491, 2007.

24. Rogers WA, Robertson MP, Lavee J. Engaging with China on organ transplantation. BMJ 2017;356:3665. https://doi.org/10.1136/bm.j. 6665

25. Ministry of Health and Family Welfare of the Republic of India. The Transplantation of Human Organs and Tissues Rules, 2014. Gazette India Extraordinary 2014;161.

26. Senate Secretariat of the Islamic Republic of Pakistan. The Transplantation of Human Organs and Tissues Act No. VI of 2010

27. Padilla B, Danovitch GM, Lavee J. Impact of legal measures to prevent transplant tourism: The interrelated experience of the Philippines and Israel. Med Health Care Philos 2013;16:915-919. https:// doi.org/10.1007/s11019-013-9473-5

28. Congress of the Philippines. Organ Donation Act. Republic Act No. 7170 of 1991.

29. Brazilian Ministry of Health. Technical Regulation of the National Transplant System. Ordinance 2600 of 2009 .

30. Arab Republic of Egypt. Law regulating human organ transplants No. 5 of 2010 as amended (Law No. 142 2017).

31. Eurotransplant Manual. Version 6, 22 May 2019, chapter 2: The Recipient. https://www.eurotransplant. org/patients/eurotransplant-manual/ (accessed 17 May 2021).

32. Cantelle C, Laurens C, Luciolli E, Loty B, Tuppin P. Access to kidney transplantation in France of nonCantelle C, Laurens C, Luciolli E, Loty B, Tuppin P. Access to kidney transplantation in France of non-
French patients and French patients living in overseas territories. Transplantation 2006;81(8):1147-1152. French patients and French patients living in overseas
https://doi.org/10.1097/01.tp.0000205182.96861.3a

33. Greenberg R, Ballesteros-Gallego F, Allard J, Fortin M-C. Organ transplantation for foreign nationals in Canada: A survey of transplant professionals. Can J Kidney Health Dis 2019;6:1-11. https://doi. org/10.1177\%2F2054358119859530

34. National Health Service Blood and Transplant. Patient selection and organ allocation policies (POL200/4.1). 2018. https://www.odt.nhs.uk/transplantation/tools-policies-and-guidance/policiesand-guidance/ (accessed 21 May 2021)

35. Glazier AK, Danovitch GM, Delmonico FL. Organ transplantation for nonresidents of the United States: A policy for transparency. Am J Transplant 2014;14(8):1740-1743. https://doi.org/10.1111/ajt.12770

36. Barsoum RS, Khalil SS, Arogundade FA. Fifty years of dialysis in Africa: Challenges and progress. Am J Kidney Dis 2015;65(3):502-512. https://doi.org/10.1053/j.ajkd.2014.11.014 
37. Ejoke UP, Ani KJ. A historical and theoretical analysis of xenophobia in South Africa. J Gender Information Dev Africa 2017;6(1-2):163-185.

38. Tella $\mathrm{O}$. Understanding xenophobia in South Africa: The individual, the state, and the international system. Insight Africa 2016;8(2):142-158. https://doi.org/10.1177\%2F0975087816655014

39. United Nations, Department of Economic and Social Affairs, Population Division. International migration 2019: Report (ST/ESA/SER.A/438). 2019. https://www.un.org/en/development/desa/ population/migration/publications (accessed 21 May 2021)

40. Segatti A, Landau LB, eds. Contemporary Migration to South Africa: A Regional Development Issue. Washington DC: World Bank, 2011. https://doi.org/10.1596/978-0-8213-8767-2

41. Crush J, Chikander A. South-South medical tourism and the quest for health in Southern Africa. Soc Sci Med 2015;124:313-320. https://doi.org/10.1016/j.socscimed.2014.06.025
42. Jones E, Rayner BL, Effa EE, Okpechi IG, Schmitz M, Heerling PJ. Survey on available treatment for acute kidney injary in the Southern African Development Community and Nigeria: Are we ready for be

43. Ereselo v Minister of Health 2019 (19/15448) SA (G).

Accepted 22 April 2021. 